\title{
A Deseda-tó környékének fullánkos hártyásszárnyú (Hymenoptera, Aculeata) faunája
}

\author{
JóZAN ZsOLT
}

H7453 Mernye, Rákóczi u. 5., Hungary, e-mail: jozan.zsolt@citromail.hu

\begin{abstract}
Józan, Zs.: A Deseda-tó környékének fullánkos hártyásszárnyú (Hymenoptera, Aculeata) faunája.
\end{abstract}
Abstract: The Deseda lake is situated in the southwestern part of Hungary, in Somogy county. The author collected a lot of Aculeata species around the lake (Table 1). The highest number of species per family: Halictidae, Colletidae, Andrenidae, Crabronidae and Vespidae. The lowest number of species were found from the Pompilidae and the Melittidae families. Genuses with the most significant number of species: Chrysis (Chrysididae), Priocnemis (Pompilidae), Crossocerus, Diodontus, Ectemnius, Passaloecus, Psenulus, Trypoxylon (Crabronidae), Andrena (Andrenidae), Bombus, Nomada (Apidae), Hylaeus (Colletidae), Halictus, Lasioglossum, Sphecodes (Halictidae), Chelostoma, Coelioxys, Osmia (Megachilidae). Only a few species were found from the Cerceris, Tachysphex (Crabronidae), Amegilla, Ceratina (Apidae) genuses. Rare species: Chrysis pseudobrevitarsis, Chrysura trimaculata, Hedychridium elegantulum (Chrysididae), Ceropales pygmaea, Dipogon vechti (Pompilidae), Methoca ichneumonides (Tiphiidae), Podalonia affinis (Sphecidae), Alysson tricolor, Crossocerus tarsatus, Crossocerus ovalis, Didineis lunicornis, Entomognathus brevis, Mimesa equestris, Miscophus niger, Passaloecus clypealis, Passaloecus insignis, Passaloecus pictus, Rhopalum gracile (Crabronidae), Andrena enslinella, Andrena hedikae, Andrena schlettereri (Andrenidae), Bombus paradoxus, Nomada argentata, Nomada braunsiana, Nomada emarginata, Nomada hirtipes, Nomada platythorax, Nomada posthuma (Apidae), Colletes mlokossewiczi, Hylaeus cardioscapus (Colletidae), Coelioxys obtusa, Hoplitis papaveris, Megachile genalis, Stelis iugae (Megachilidae). Also, the zoogeographical (Table 2,4) and the ecofaunistical (Table 3,5) analyses are given of the species collected.

Keywords: South Transdanubia, Deseda lake, Hymenoptera, Aculeata, rare species, zoogeographical character, ecofaunistical character, biodiversity

\section{Bevezetés}

A Dél-Dunántúlon az elmúlt évtizedekben számos védett terület faunisztikai vizsgálata zajlott. Ezek kiterjedtek a fullánkos hártásszárnyú fajokra is. Vizsgáltuk a Barcsi Borókás TK, a Béda-Karapancsa TK, a Boronka-melléki TK, a Baláta-tó TVT, a Látrányi Puszta TVT, a Zselici TK, a Villányi-hegység és a Duna-Dráva NP faunáját. A kutatások eredményeit publikáltuk (JózAN 1990, 1992a, 1992b, 1992c, 1996, 1998, 2000a, 2003, 2015). A szerző ezek mellett a Dél-Dunántúlon másutt is rendszeres, öt évtizedet átfogó gyüjtőmunkát folytatott. Nagyon gazdag adatanyag gyült össze az 1974-ben létesített Deseda-tó környékéről is. A tó Magyarország egyik leghosszabb mesterséges tava, nemzetközi jelentőségü horgászterület, ugyanakkor helyi jelentőségü védett terület is. Ezek indokolttá teszik az innen előkerült fajok publikálását, a fauna értékelését. 


\section{Anyag és módszer}

A Deseda három település közigazgatási területéhez tartozik: Kaposvár, Magyaregres és Somogyaszaló. A tó déli részét Kaposvár két része, keletről Toponár, nyugatról Kaposfüred határolja. A szerző a gyüjtéseket a 70-es évek elejétől 2020-ig rendszeresen folytatta, minden évben többször is felkereste a tó és környékének számos pontját. Az utóbbi évtizedben a gyüjtésekbe Sasvári Mária is bekapcsolódott. A tópart két nagyobb tölgyesét vizsgáltuk: keleten a Somogyaszalóhoz tartozó Deseda erdőt és az északnyugati tópartot övező, Kaposfüred területéhez tartozó Gombás erdőt. A Deseda erdő nyugati kitettségü szegélyén különösen eredményes gyüjtőmunkát folytattunk. Két kisebb tölgyfragmentum területén is gyüjtöttünk a tó duzzasztó gátja közelében és a keleti oldalon a vízi sporttelep mellett. Dolgoztunk a tó északi félszigetén a Magyaregreshez tartozó arborétumban is. Itt gyeptársulásokban és cserje szegélytársulásokban hálóztunk. A duzzasztógát nyugati- és keleti oldalán a nádszegélyben, az ezt övező üde gyeptársulásokban, mocsári társulásokban, a tótól távolabb útpadkákon és cserjések szegélytársulásaiban dolgoztunk.AKaposfüred és Toponár községi szőlőhegyein gyepfragmentumokban, útszegélyeken hálóztunk. Kaposfüreden, a tó nyugati partja mentén is vizsgálódtunk. A három község belterületén eredményes gyüjtéseket folytattunk gyepfragmentumokban, útpadkákon, gyomtársulásokban. Mindhárom településen sikerült levéltetűvel fertőzött hársfákon és őszibarack fákon eredményes lombhálózást végezni. A régi épületek falazatán gazdag fullánkos fajegyütteseket találtunk. A módszer a lepkehálóval történő egyelő gyüjtés, fü- és lombhálózás volt. Csapdákat nem alkalmaztunk. A vizsgálat nem terjedt ki a Formicidae, a Bethylidae, az Embolemidae és a Dryinidae családokra.

\section{Eredmények és értékelés}

Az öt évtizedes, a rajzási idő teljes tartamára kiterjedő munka jelentős számú faj kimutatását tette lehetővé. A gyüjtött mintegy 2500 példányból 650-700 a Rippl-Rónai Megyei Hatókörü Városi Múzeum rovargyüjteményébe került. Az előkerült fajok száma 559. Ezek 15 családba és 126 nembe tartoznak.

A kimutatott fajok jelentős száma - más vizsgált területekkel összevetve - a hosszú évtizedekig történő rendszeres gyüjtőmukának is köszönhető (1. táblázat). A Chrysididae család fajszáma jelentős. A hazai fajok egynegyede került elő a vizsgált területről, ám a ritka Cleptinae fajok közül csak egyet sikerült megtalálni. A Chrysidinae alcsaládnál az Elampini tribus fajszáma 18, a Chrysidini fajszáma 26. Az előbbiek a föleg a talajban fészkelő fullánkosok kleptoparazitái. Az utóbbi taxon fajait túlnyomóan a települések területén öreg épületek falazatán gyüjtöttük, ahol a gazdaállatok fészkelnek. A faunisztikai szempontból jeletősebb fajok: Hedychridium elegantulum, Chrysis pseudobrevitarsis, Chrysis solida, Chrysis subsinuata, Chrysis taczanovskii. Ez utóbbi faj az elmúlt egy-két évtizedben egyre több lelőhelyen kerület elő, ezek túlnyomó többsége a Dél-Dunántúlon található.

A Mutillidae fajok száma nagyon alacsony. A Magyarország területéröl ismert 31 fajból csak négyet sikerült megtalálni, mindegyik gyakori állat. A 7 hazai Scoliidae faj közül egyet gyüjtöttünk. Ez azzal van összefüggésben, hogy a fajok elsősorban homokvidékeken elterjedtek, a Deseda pedig Külső-Somogy lösztakaróján fekszik.

A Pomplidae fajok száma viszonylag alacsony, a hazai fajok $20 \%$-ánál alig több került itt elö.

A Priocnemis fajok közül 10-et sikerült megtalálni. Ez a hazai fajok egyharmadánál is 
több. Jellemző élőhelyük tavasszal a tölgyesek gyeptársulása. Nyáron gyepekben és útszegélyeken, Apiaceae virágokon hálóztuk példányait. A régi épületek falazatán az Agenioideus és Auplopus fajok jellemzőek. Itt keresik a pókzsákmányukat és fészkelőhelyeiket. A család fajainak többsége gyakori. Faunisztikai szempontból a legjelentősebb a ritka, Európa középső és északi tájain elterjedt Dipogon vechti. A DélDunántúlon csak a Deseda-erdőben és Nagybajom környékén gyüjtöttük (JózAN 1992b). Az elmúlt évszázad első felében előkerült Simontornyán (MóczÁR L. 1956), a második felében pedig Csévharaszton (MóczáR L. 1986). Ritkának bizonyul még a Priocnemis enslini is.

A Vespidae család fajainak száma sokkal jelentősebb, a Magyarországon kimutatott fajok 40\%-át gyüjtöttük a vizsgált területen. A Vespinae alcsalád fajainak mintegy fele került elö. Ezek gyakoriak, színező faunaelem nincs közöttük. Az Eumeninae alcsalád esetében a nemek száma elég magas. Az Eumenes fajok száma kevés. A régi épületek falazatán az Antepipona orbitalis, a Jucancistrocerus jucundus és a Symmorphus murarius fészkelését figyelhettük meg. Ritkább fajok a Discoelius zonalis és a Parodontodynerus ephippium. Az előbbi a hűvös-nedves, az utóbbi a meleg-száraz élöhelyek kedvelöje.

A 27 hazai Sphecidae fajból 8 került elö. A Podalonia affinis példányait több évtizeddel ezelőtt gyüjtöttük. A Dél-Dunántúlon csak a két megjelölt lelöhelyen fogtuk. Két invazív fajt mutattunk ki: a Sceliphron curvatum a kezdeti dinamikus terjedési időszakhoz képest az utóbbi években jóval ritkábban mutatkozott. Az Isodontia mexicana pedig az elmúlt években nagyon intenzív expanziót mutatott, a család egyik gyakori fajává lett. Ötvennél is több gyüjtöhelyen találtuk meg.

A Crabronidae család előkerült fajainak száma a Magyarországon kimutatottak 43\%-a. Az Astatinae fajok száma nagyon alacsony. Közöttük ritkább nem található. A Bembicinae alcsalád fajainak részesedése átlagos, a hazánkból kimutatottak 30\%-a. A Gorytes fajok száma a legmagasabb, a tóparti gyeptársulások, útszegélyek mocsárrét fragmentumok Apiaceae fajainak virágain (Angelica sylvetris, Daucus carota, Pastinaca sativa) repültek. Ezek fészekparazitái a Nysson fajok. Közülük négyet sikerült gyüjteni. Ritkább fajok: Alysson tricolor, Didineis lunicornis, Harpactus elegans. A legnépesebb alcsalád a Crabroninae, a hazai faunában kimutatott 126 faj 46\%-a került elő a vizsgált területen. A 20 magyarországi genus közül 15-öt sikerült megtalálni. A Corossocerus és az Ectemnius fajok felét gyüjtöttük. Az utóbbiak fatörzsek elhagyott bogárjárataiban építik ivadékbölcsőiket. A Deseda környéke meglehetősen erdősült, így ez az Ectemnius fajok számára kedvez. A 8 hazai Trypoxylon fajból 5-öt mutattunk ki. Az Oxybelus fajok száma nem olyan jelentős, a faunánkban ismertek közül még a felét sem tudtuk megtalálni. Ez azzal is összefügg, hogy e fajok közül sok a homokterületeket kedvelő állat. A vizsgált terület környékén csak a tótól keletre van egy kisebb völgyválli, erösen kötött homoktakaró. Ez mutatkozik meg a Tachysphex fajok nagyon alacsony számában is. Minössze 3 fajukat találtuk meg. Közülük a T. tarsinus többnyire a régi épületek téglafalazatán tevékenykedik, hasonlóan a Miscophus, a Pison és a Trypoxylon fajokhoz. A Rhopalum fajok ritkák. Az 5 hazánk faunájából ismert közül 2 került elő. A 7 magyarországi Lindenius fajból az 5 gyakoribbat sikerült kimutatnunk. Az Entomognathus dentifer ritka, a Dunántúlon a múlt évszázad első évtizedeiből csak 5 lelőhelyét közölték (MóczÁr L. 1958). A szerző mindössze Kaposfüreden, a Gombás erdőben gyüjtötte. A 6 hazánkból kimutatott Miscophus faj fele előkerült. A Miscophus niger az utóbbi évtizedekben került elő hazánkban, a szerző gyüjtéseinek köszönhetően. Eddig 4 lelöhelyét ismerjük (JózAN 2008), ezek egyike Somogyaszaló: Antalmajor. Mindkét Nitela fajunkat sikerült gyüjteni a vizsgált területen.

A Mellinae alcsaládnak Európában csak 2, Magyarországon 1 faja ismert. 
Somogyaszalóban tetüvel fertőzött hársfa lombján találtuk meg.

A Pemphredoninae alcsalád hazai fajainak száma 60. A Deseda környékén ezek fele került elő. A nemek közül jelentősebbek: Diodontus, Passaloecus, Psenulus. Ezek fajszáma meghaladja a Magyarországon gyüjtött fajok 50\%-át. A 10 hazai Pemphredon fajból 5-öt tudtuk kimutatni. Ezzel szemben kevés Ammoplanus, Mimesa és Mimumesa fajt sikerült megtalálni, ám valamennyi Stigmus és Spilomena faj előkerült. A Pemphredoninae fajok többségét főleg a levéltetüvel fertőzött hárs- és őszibarack fák lombján hálóztuk. Ritkább fajok: Passaloecus clypealis, Passaloecus insignis, Passaloecus pictus, Pemphredon morio, Psen ater, Spilomena beata, Spilomena mocsaryi.

A Passaloecus pictus az utóbbi évtizedekben került elö Magyarországon. A tucatnyi lelőhely, egy kivételével mind a Dél-Dunántúlon van (Józan 2008, 2020).

A Philanthinae alcsalád hazai fajainak $46 \%$-át sikerült megtalálni a tó környékén. Közöttük csak gyakori fajokat találhatunk.

A méhcsaládok (Anthophila) közül a legfajgazdagabbnak a Halictidae bizonyult, a hazánkból kimutatott fajok több, mint 53\%-a került elő. A Halictus és Sphecodes fajok 60, a Lasioglossum fajok 50\%-át találtuk meg. Faunisztikai szempontból jelentősebbek: Halictus leucaheneus, Lasioglossum buccale, Lasioglossum costulatum, Lasioglossum laeve, Lasioglossum puncticolle, Specodes crassus, Sphecodes rubicundus, Sphecodes scabricollis. A vizsgált területen nem gyütöttük a homokkedvelő Nomioides minutuissimus és Ceylalictus variegatus fajokat. Túlnyomórészt a hegyvidékeinken élő ritka Dufourea fajok közül egyiket sem találtuk meg. Ezek közül a Dél-Dunántúlon csak az D. inermis került elő a Villányi-hegységben (MóczáR M. 1967).

A Magyarországon ismert Colletidae fajok 46\%-át sikerült gyüjtenünk. A Colletes fajok száma nagyon alacsony, az ország területéről elökerültek mintegy egynegyed részét tudtuk megfogni. Csak a C. mlokossewiczi mondható ritkábbnak. A kimutatott Hylaeus fajok száma viszont jelentős, a magyarországi faunában szereplők 60\%-a. Faunisztikai szempontból jelentősebbek: Hylaeus cardioscapus, Hylaeus difformis, Hylaeus punctulatissimus.

Andrenidae fajaink közel 45\%-át mutattuk ki. Ritkább fajok: Andrena chrysosceles, Andrena denticulata, Andrena enslinella, Andrena fulva, Andrena fulvata, Andrena impunctata, Andrena marginata, Andrena nasuta, Andrena saxonica, Andrena schlettereri, Andrena strohmella. Az Andrena hedikae nagyon ritka, melegkedvelö mediterrán bányászméh-fajunk. A Dél-Dunántúlon csak a Mecsek egyetlen, és a Villányi-hegység két pontján került elő (MóczÁR \& WARNCKE 1972, JózAN 2006). A szerző megtalálta Görcsöny belterületén is. A kora tavaszi aszpektusban a tölgyesek gyepszintjében és a szegélyeken jellemzö fajok: Andrena bicolor, Andrena cineraria, Andrena dorsalis, Andrena dorsata, Andrena fulvata, Andrena gravida, Andrena haemorrhoa, Andrena helvola, Andrena minutula, Andrena subopaca. A család fajszegény nemei közül csak 2 képviselöje került elö. A Panurgus calcaratus gyakori, a Melitturga clavicornis itt nagyon ritka, csak a múlt század 80-as éveiben fogtuk.

A vizsgált területen a hazai Megachilidae fajok közel 42\%-át gyüjtöttük. A magyarországi faunában a család 12 nemét ismerjük. A Deseda környékén ezek közül csak a Trachusa és a Dioxys s.l. nem került elö. A Hoplosmia, a Lithurgus és a Heriades nemek szintén kis fajszámúak, de képviselői a gyüjtések során elökerültek. A legmagasabb a Chelostoma fajok száma, a 9 magyaroszági fajból 7 került elő. Ezt követik az Osmia fajok, a hazaiak 63\%-át gyüjtöttük. Majd következnek a Coelioxys fajok 53\%-kal. A Megachile fajok száma is jelentős, bár nem éri el a Magyarországon ismertek felét. Az Anthidium, és Stelis fajok száma alacsony. Faunisztikai szempontól jelentősek: Coelioxys obtusa, Hoplitis papaveris, Stelis ingae.

Az Apidae család nálunk ismert 21 nemének mintegy fele a vizsgált területen is előke- 
rült. A család desedai fajszáma a többi családhoz hasonlítva alacsony. A Magyarországon kimutatott fajok valamivel több, mint egyharmadát sikerült gyüjteni. A legjelentősebb a Nomada nem: a hazai fajok 43\%-át találtuk meg a Deseda környékén. Ezek közül a tó keleti és nyugati partját övező tölgyesek avarszintjén a Nomada alboguttata, $N$. atroscutellaris, $N$. bifasciata, $N$. braunsiana, $N$. fabriciana, $N$. ferruginata, $N$. flava, $N$. flavoguttata, $N$. hirtipes, $N$. panzeri a kora tavaszi aszpektusban volt gyüjthetö. Magyarországon ritkák: $N$. argentata, $N$. braunsiana, $N$. hirtipes, $N$. incisa, $N$. platythorax, N. posthuma, N. stigma. A N. posthuma hazánkban 3 lelöhelyről került elö, ezek egyike a Deseda-tó. A $N$. platythorax nálunk 6 lelöhelyröl ismert. Két típuspéldánya a közeli Mernyéről került elő (JózAN 2000b). E ritka fajokat föleg gyeptársulásokban találtuk meg, a kétszikü növények virágain táplálkozva. A Bombus fajok száma is figyelemre méltó, de közöttük csak egy mondható ritkának: B. paradoxus. A 8 hazai Psithyrus fajból mindössze 1 került elö. Ezeket a fajokat a szakirodalomban általában a Bombus nembe sorolják. A többi Apidae nem fajainak száma nem éri el a Magyarországról ismert fajok 30\%-át. Az 5 Amegilla fajunkból csak a leggyakoribbat gyüjtöttük. A Thyreus fajok az előbbiek kleptoparazitái, közülük a T. ramosus gyakori, a T. orbatus ritkának mondható. A Pasites maculatus a Nomiapis diversipes parazitája. A múlt század végén még ritkának tartottuk, de az utóbbi évtizedben egyre több helyen gyüjtöttük. A 7 hazai Ceratina fajból csak 3 került elő gyüjtéseink során.

A magyarországi Melittidae fajok száma 16. A vizsgált területen ezekből csak 5 került elő. A két Macropis faj és a Melitta nigricans hüvösebb, nedvesebb élöhelyeket kedvel. A Dasypoda hirtipes és a Melitta leporina szárazabb gyepekben, útszegélyeken táplálkozik, gyakori faj.

A darázscsaládok fajainak többsége széles elterjedésü (holarktikus, palearktikus, nyugat-palearktikus és euroszibériai) állat. A Vespidae fajok 70, a Chrysididae fajok 55\%-a tartozik ebbe a csoportba. A Pompilidae, Sphecidae és Crabronidae fajok esetében ez az érték a legalacsonyabb, 44-45\%. A Chrysidiae és Pompilidae fajok között van a legtöbb mediterrán faj, 44-45\%. Európai elterjedési jellegű állatokat csak a Sphecidae és Crabronidae családoknál találtunk (2. táblázat). A méhszerü családok esetében a széles elterjedésüek részesedése 36 és $65 \%$ között ingadozik. A legmagasabb értéket a Halictidae- és Colletidae- (64-65\%), a legalacsonyabbat az Apidae fajok között találtunk (36-37\%). A Megachilidae és Andrenidae családoknál ez az érték 42-46\% között váltakozott. A mediterrán fajok részesedése a Megachilidae családban a legmagasabb, 38\%. Ettől valamennyivel elmarad az Andrenidae család, kerekítve 34\%-kal. A Halictidae és Apidae fajoknál ez az arány $21 \%$ és $25 \%$. A legalacsonyabb a mediterrán faunaelemek aránya a Colletidae fajoknál, mindössze 16\%. Az európai elterjedésü fajok részesedése $14 \%$ és $33 \%$ között változik. A legalacsonyabb a Halictus, a legmagasabb az Apidae fajok esetében. Ez utóbbi érték főleg a Nomada fajok miatt alakult ki (4. táblázat).

A Chrysidiae fajok több mint háromnegyed része melegkedvelő (stenoök és euryök eremophil). E fajok részesedése a Sphecidae, Crabronidae és Vespidae fajok esetében 42-45\% között van. A Pompilidae fajok között csupán 22\%-nyi melegkedvelöt találtunk. A széles türéshatárú (hiepereuryök) faunaelemek részaránya - az előző értékekkel összefüggésben - éppen a Pompilidae fajoknál a legmagasabb, 52\%. A Vespidae család estében ez az érték 35\%, a Sphecidae, Crabronidae és Chrysididae fajoknál csak 19-20\%. A hűvösebb-nedvesebb élőhelyeket preferáló (euryök hylophil) faunaelemek részaránya legmagasabb a Sphecidae-Crabronidae családokban, meghaladja a 35\%-ot. A Pompilidae és Vespidae fajoknál ez a részarány $22 \%$ és $26 \%$ között váltakozik. A Chrysididae fajoknál ezek részesedése nagyon alacsony, kerekítve csupán $\%$ (3. táblázat). Az eremophil fajok részesedése a Megachilidae család esetében a legmagasabb, 56\%. Ezt követik a Halictidae és Apidae fajok 51 illetve 44\%-kal. Az Andrenidae és Colletidae családban 
ezek részaránya 32 és 36\% között van. A hipereuryök faunaelemek száma a Halictidae családban közel 40\%. Valamivel alacsonyabb ez az érték a Colletidae fajok esetében: 36\%. Az Andrenidae fajoknak csak 28-29\%-a esik ebbe a körbe. Az Apidae és Megachilidae család fajainak csupán 17-18\%-a széles türéshatárú. A hűvös-nedves élőhelyeket kedvelők aránya a legmagasabb az Andrenidae- és Apidae családokban, meghaladja a 38\%-ot, a Colletidae családban már csak 28\%. A Megachilidae fajoknál ez az érték még alacsonyabb, $25 \%$. Feltünően alacsony ezek részaránya a Halictidae család fajainál, mindössze $9 \%$ (5. táblázat).

1. táblázat: A Deseda környékén és néhány más vizsgált területen előkerült Aculeata fajok száma családonként

\begin{tabular}{|c|c|c|c|c|c|c|c|}
\hline \begin{tabular}{|l|} 
Családok \\
\end{tabular} & Deseda & Béda & \begin{tabular}{|l|} 
Boronka \\
\end{tabular} & Bares & Látrány & Órség & Baláta \\
\hline \begin{tabular}{|l|} 
Chrysididae \\
\end{tabular} & 45 & 19 & 36 & 28 & 30 & 25 & 36 \\
\hline Sapygidae & 2 & 2 & 2 & 1 & 0 & 2 & 1 \\
\hline \begin{tabular}{|l|} 
Tiphiidae \\
\end{tabular} & 3 & 1 & 5 & 3 & 4 & 2 & 2 \\
\hline \begin{tabular}{|l|} 
Mutillidae \\
\end{tabular} & 4 & 4 & 7 & 7 & 7 & 4 & 5 \\
\hline Scoliidae & 1 & 1 & 2 & 2 & 3 & 0 & 2 \\
\hline Pompilidae & 27 & 14 & 50 & 35 & 34 & 25 & 25 \\
\hline Vespidae & 40 & 27 & 35 & 24 & 19 & 34 & 26 \\
\hline Ampulicidae & 0 & 0 & 0 & 1 & 0 & 1 & 1 \\
\hline Sphecidae & 8 & 3 & 7 & 9 & 10 & 4 & 8 \\
\hline Crabronidae & 122 & 62 & 131 & 106 & 94 & 78 & 88 \\
\hline Andrenidae & 70 & 45 & 63 & 37 & 53 & 46 & 38 \\
\hline Apidae & 76 & 39 & 56 & 35 & 38 & 46 & 47 \\
\hline Colletidae & 25 & 17 & 22 & 17 & 20 & 22 & 16 \\
\hline Halictidae & 77 & 52 & 66 & 56 & 51 & 50 & 49 \\
\hline Megachilidae & 55 & 23 & 46 & 32 & 36 & 34 & 35 \\
\hline Melittidae & 5 & 5 & 6 & 4 & 4 & 4 & 3 \\
\hline Összesen: & 559 & 314 & 534 & 397 & 303 & 377 & 382 \\
\hline
\end{tabular}

2. táblázat: A darázsfajok százalékos megoszlása elterjedési jellegük szerint

\begin{tabular}{|l|c|c|c|c|}
\hline & $\begin{array}{c}\text { Sphecidae és } \\
\text { Crabronidae }\end{array}$ & Chrysididae & Pompilidae & Vespidae \\
\hline holarktikus & 5,4 & - & 3,7 & - \\
\hline palearktikus & 31,6 & 40 & 40,8 & 40 \\
\hline nyugat-palearktikus & 5,4 & 15,5 & - & 22,5 \\
\hline euroszibériai & 1,5 & - & - & 7,5 \\
\hline mediterrán & 26,2 & 44,5 & 44,5 & 30 \\
\hline európai & 29,1 & - & - & - \\
\hline egyéb & 0,8 & - & - & - \\
\hline összesen & $\mathbf{1 0 0}$ & $\mathbf{1 0 0}$ & $\mathbf{1 0 0}$ & $\mathbf{1 0 0}$ \\
\hline
\end{tabular}


3. táblázat: A darázsfajok százalékos megoszlása ökofaunisztikai jellegük szerint

\begin{tabular}{|l|c|c|c|c|}
\hline & $\begin{array}{c}\text { Sphecidae és } \\
\text { Crabronidae }\end{array}$ & Chrysididae & Pompilidae & Vespidae \\
\hline stenoök eremophil & 0,8 & 2,2 & - & - \\
\hline eryök eremophil & 44,6 & 75,6 & 22,2 & 42,5 \\
\hline hipereuryök intermedier & 19,2 & 20 & 51,9 & 35 \\
\hline euryök hylophil & 35,4 & 2,2 & 25,9 & 22,5 \\
\hline összesen & $\mathbf{1 0 0}$ & $\mathbf{1 0 0}$ & $\mathbf{1 0 0}$ & $\mathbf{1 0 0}$ \\
\hline
\end{tabular}

4. táblázat: A méhfajok százalékos megoszlása elterjedési jellegük szerint

\begin{tabular}{|l|c|c|c|c|c|}
\hline & Andre nidae & Apidae & Colletidae & Halictidae & Megachilidae \\
\hline holarktikus & - & - & - & 3,9 & - \\
\hline palearktikus & 15,7 & 9,2 & 36 & 30,3 & 20,2 \\
\hline nyugat-palearktikus & 14,3 & 14,4 & 16 & 22,4 & 18,4 \\
\hline euroszibériai & 15,7 & 13,1 & 12 & 7,9 & 3,7 \\
\hline mediterrán & 34,3 & 25,1 & 16 & 21,1 & 38,4 \\
\hline európai & 18,6 & 33 & 16 & 14,4 & 18,4 \\
\hline egyéb & 1,4 & 5,2 & 4 & - & 0,9 \\
\hline összesen & $\mathbf{1 0 0}$ & $\mathbf{1 0 0}$ & $\mathbf{1 0 0}$ & $\mathbf{1 0 0}$ & $\mathbf{1 0 0}$ \\
\hline
\end{tabular}

5. táblázat: A méhfajok százalékos megoszlása ökofaunisztikai jellegük szerint

\begin{tabular}{|l|c|c|c|c|c|}
\hline & Andre nidae & Apidae & Colletidae & Halictidae & Megachilidae \\
\hline stenoök eremophil & - & - & - & - & - \\
\hline eryök eremophil & 32,8 & 44,8 & 36 & 51,3 & 56,3 \\
\hline hipereuryök intermedier & 28,6 & 17 & 36 & 39,5 & 18,4 \\
\hline euryök hylophil & 38,6 & 38,2 & 28 & 9,2 & 25,3 \\
\hline összesen & $\mathbf{1 0 0}$ & $\mathbf{1 0 0}$ & $\mathbf{1 0 0}$ & $\mathbf{1 0 0}$ & $\mathbf{1 0 0}$ \\
\hline
\end{tabular}

\section{Természetvédelmi értékelés}

A több évtizedig történő gyüjtések alkalmával megfigyelhettünk olyan változásokat, amelyek a fullánkos fauna diverzitása szempontjából kedvezőtlennek bizonyultak. A tó nádszegélye mellett kialakult sás- és gyepzóna a tó kialakítása utáni években jelentős tápanyagforrást szolgáltatott az Aculeata fajoknak, mert sokféle nektár- és pollentermelő növényfaj telepedett itt meg. A tóhoz kötődő horgászati tevékenység együtt járt a helytelen szemléletű kezeléssel. Egyre több helyen ezt az övezetet nyírni kezdték, és „,parkosították" a tó mellékét. Ezt a tevékenységet már áprilisban elkezdik, néhány helyen még a tölgyfacsoportok aljnövényzetét sem kímélve. A toponári oldalon a duzzasztógát közelében kialakítottak egy szabadstrandot. Itt a gyep rendszeres nyírásán túl gyorsan növekvö fákat is telepítettek, hogy a strandolók kényelmét szolgálják az árnyékolással. Ezen a területen a múlt század 80-as éveiben még sok fajt tudtunk megfigyelni. A lágyszárú növényzet kaszálását a tó északi részén található arborétumban is elvégzik, bár ez kevésbé ártalmas a fullánkosoknak, mert kedvezőbb időszakban történik. A Deseda menti tölgyesekben is történt tarvágás. Egy kisebb, feltételezhetően magántulajdonú területen kiirtották a cserjeszintet. Ezzel jelentősen megnőtt a szél szárító hatása, a fényviszonyok is megváltoztak. A községi szőlőkben is jelentős változás történt az évtizedek során. A 
régebben sokfelé meghagyott, présház melletti gyepfragmentumokat, útszegélyeket egyre rendszeresebben kaszálják. A régebben kézi kaszával történő kezelést felváltotta zsinóros motoroskaszák használata. Ezek sokkal jelentősebb károsodást okoznak a növényzetnek, mint a hagyományos kaszálás. A kíméletesebb kezelés mellett a kétszikü növények sarjhajtásai is kivirágoztak. Napjainkban már erre kisebb az esély. A hagyományos építésű présházak falazata, fa építőelemei gazdag fészkelési lehetőségeket nyújtottak a fullánkos fajoknak. Ezeket az építményeket lebontották, vagy korszerüsítették. A modern építőanyagok alkalmazása miatt a fajok fészkelési lehetőségei nagyon beszükültek. A hagyományosan alkalmazott növényvédő szereket felváltó vegyületek jóval ártalmasabbak a rovarfaunára. A településeken a közterületek kezelése is egyre intenzívebbé vált. A rézsűk, árokpartok, útszegélyek gyepjei is az előzőekben leírtak sorsára jutottak. Sokszor a növények töveit is összezúzzák a nagy teljesítményü gépekkel. A kedvezőtlen hatásokat a dísznövények kultiválása csak részben ellensúlyozza. A községek külterületén valaha a közösségi legelökön (fás legelök) a hagyományos intenzitású legeltetés mellett gazdag kétszikü növényet tenyészett, és gazdag fullánkos faunát táplált. A talajban a fészkelési lehetőségek is kedvezőek voltak. A legeltetés elmaradása miatt a szukcessziós folyamatok és a degradáció következtében ezek a feltételek gyakorlatilag megszüntek.

\section{A gyüjtött fajok jegyzéke}

Rövidítések:

$\mathrm{KGe}=$ Kaposfüred, Gombás-erdő; Ksz = Kaposfüred, szőlőhegy; MDa = Magyaregres, Deseda arborétum; $\mathrm{Mbt}=$ Magyaregres belterülete; $\mathrm{Sbt}=$ Somogyaszaló belterülete; $\mathrm{SD}=$ Somogyaszaló, Deseda erdö; Tbt $=$ Toponár belterülete; TD = Toponár, Deseda gát környéke; Ts = Toponár, vízi sporttelep környéke; Tsz = Toponár, szőlöhegy

\section{CHRYSIDOIDEA}

CHRYSIDIDAE: CLEPTINAE

Cleptes semiauratus (Linnaeus, 1761) - Ksz

\section{CHRYSIDIDAE: CHRYSIDINAE: ELAMPINI}

Hedychrum gerstaeckeri Chevrier, 1869 - TD, Sbt Hedychrum niemelai Linsenmaier, 1959 - Ksz, Sbt, TD

Hedychrum nobile (Scopoli, 1763) - Ksz, TD

Hedychrum rutilans (Dahlbom, 1854) - Ksz, Sbt, TD

Hedychridium ardens (Coquebert, 1801) - TD

Hedychridium coriaceum (Dahlbom, 1854) - Sbt, TD

Hedychridium elegantulum Buysson, 1887 - Sbt

Hedychridium jucundum (Mocsáry, 1880) - Sbt

Hedychridium mediochrum Linsenmaier, 1987 - TD

Hedychridium monochroum Buysson, 1888 - Sbt

Hedychridium roseum (Rossi, 1790) - TD

Holopyga generosa (Förster, 1853) - Sbt, TD

Holopyga ignicollis Dahlbom, 1854 - Sbt

Holopyga inflammata (Förster, 1853) - KGe

Omalus aeneus (Fabricius, 1787) - Kge, Sbt

Pseudomalus auratus (Linnaeus, 1758) - Ksz, Sbt, SD, TD

Pseudomalus bidentulus (Lepeletier, 1806) - Ksz Pseudomalus pusillus (Fabricius, 1804) - Mbt, Sbt, Tsz

CHRYSIDIDAE: CHRYSIDINAE: CHRYSIDINI Chrysidea disclusa (Linsenmaier, 1959) - Mbt, Sbt

Chrysis comta Förster, 1843 - TD

Chrysis distincta Olivier, 1790 - Sbt
Chrysis fulgida Linnaeus, 1761 - Tsz

Chrysis germari Wesmael, 1839 - Sbt Chrysis gracillima Förster, 1853 - Sbt, Tbt Chrysis graelsii Guerin, 1842 - SD, Tbt Chrysis grohmanni Dahlbom, 1854 - Mbt, Sbt Chrysis ignita (Linnaeus, 1758) - Mbt, Sbt, SD Chrysis impressa Schenck, 1856 - Sbt Chrysis inaequalis Dahlbom, 1854 - Sbt Chrysis leachii Shuckard, 1836 - Sbt, Tbt

Chrysis marginata Mocsáry, 1889 - Sbt Chrysis mediata Linsenmaier, 1951 - Sbt, SD, Tsz

Chrysis pseudobrevitarsis Linsenmaier, 1951 - TD Chrysis ragusae Destefani, 1888 - Mbt, Sbt

Chrysis rutilans Olivier, 1790 - Sbt

Chrysis scutellaris Fabricius, 1794 - Sbt

Chrysis solida Haupt, 1956 - Mbt

Chrysis subsinuata Marquet, 1879 - Sbt

Chrysis taczanovskii Radoszkovski, 1876 - Sbt

Chrysis terminata Dahlbom, 1854 - Sbt, SD

Chrysura dichroa (Dahlbom, 1854) - SD

Chrysura filiformis (Mocsáry, 1889) - Sbt

Chrysura trimaculata (Förster, 1853) - SD

Trichrysis cyanea (Linnaeus, 1758) - Sbt, SD, TD

VESPOIDEA

MUTILLIDAE

Myrmosa atra Panzer, 1801 - TD

Paramyrmosa brunnipes (Lepeletier, 1845) - TD

Myrmilla calva (Villers, 1789) - Mbt, Sbt, Tsz

Smicromyrme rufipes (Fabricius, 1787) - Sbt, KD 


\section{POMPILIDAE}

Agenioideus cinctellus (Spinola, 1808) - Sbt, Tsz Agenioideus sericeus (Vander Linden, 1827) - Sbt Anoplius caviventris (Aurivillius, 1907) - TD Anoplius nigerrimus (Scopoli, 1763) - TD Anoplius viaticus paganus (Dahlbom, 1843) - Sbt, TD

Arachnospila anceps (Wesmael, 1851) - Sbt Arachnospila minutula (Dahlbom, 1843) - Mbt, Sbt, TD

Arachnospila spissa (Schiödte, 1837) - Sd, TD

Auplopus albifrons (Dalman, 1823) - Sbt

Auplopus carbonarius (Scopoli, 1763) - Mbt, Sbt, $\mathrm{SD}, \mathrm{TD}$

Caliadurgus fasciatellus (Spinola, 1808) - Sbt, Tbt, TD

Ceropales maculata (Fabricius, 1775)

Ceropales pygmaea Kohl, 1880

Cryptocheilus versicolor (Scopoli, 1763) - Ts

Dipogon bifasciatus (Geoffroy, 1785) - KGe, Sbt,

SD

Dipogon vechti Day, 1979 - SD

Episyron arrogans (Smith, 1873) - Ts

Priocnemis agilis (Shuckard, 1837) - Tbt

Priocnemis coriacea Dahlbom, 1843 - SD

Priocnemis enslini Haupt, 1927 - SD

Priocnemis hyalinata (Fabricius, 1793) - Sbt, TD

Priocnemis melanosoma Kohl, 1880 - Sbt

Priocnemis perturbator (Harris, 1776) - KGe, MDa,

Sbt, SD, TD, Ts

Priocnemis pusilla Schiödte, 1837 - TD

Priocnemis sulci Balthasar, 1943 - KGe

Priocnemis susterai Haupt, 1927 - SD, TD

Priocnemis vulgaris (Lepeletier, 1845) - SD

\section{SAPYGIDAE}

Sapyga quinquepuctata (Fabricius, 1781) - Mbt, Sbt Sapygina decemguttata (Jurine, 107) - SD, TD

SCOLIIDAE

Scolia hirta (Schrank, 1781) - Sbt

\section{TIPHIIDAE}

Methoca ichneumonides Latreille, 1809 - TD

Tiphia femorata Fabricius, 1775 - Sbt, TD

Tiphia minuta Vander Linden, 1827 - KGe, SD

\section{VESPIDAE: VESPINAE}

Dolichovespula media (Retzius, 1783) - SD

Dolichovespula saxonica (Fabricius, 1793) - TD

Dolichovespula sylvestris (Scopoli, 1763) - Sbt

Polistes bischoffi (Weyrauch, 1939) - Ksz, TD

Polistes dominulus (Christ, 1791) - Mbt, Sbt, TD

Polistes nimpha (Christ, 1791) - Mbt, Sbt, TD

Vespa crabro Linnaeus, 1758 - SD

Vespula germanica (Fabricius, 1793) - Ksz, Sbt, TD

Vespula rufa (Linnaeus, 1758) - TD

Vespula vulgaris (Linnaeus, 1758) - TD

\section{VESPIDAE: EUMENINAE}

Alastor mocsaryi (André, 1884) - Sbt

Allodynerus delphinalis (Giraud, 1866) - Mbt, Sbt

Allodynerus rossii (Lepeletier, 1841) - SD, TD

Ancistrocerus acutus (Fabricius, 1793) - Mbt, Sbt, Tsz

Ancistrocerus gazella (Panzer, 1798) - Ksz, Sbt, SD, TD

Ancistrocerus nigricornis (Curtis, 1826) - Sbt, SD

Ancistrocerus trifascatus (Müller, 1776) - TD
Antepipona orbitalis (Herrich-Schaeffer, 1839) - Mbt, Sbt, TD

Discoelius zonalis (Panzer, 1801) - SD

Eumenes coronatus (Panzer, 1799) - TD

Eumenes papillarius (Christ, 1791) - Ts, TD

Eumenes pedunculatus (Panzer, 1799) - Mbt

Euodynerus notatus (Jurine, 1807) - Sbt, Tsz Gymnomerus laevipes (Shuckard, 1837) - Sbt, KD

Jucancistrocerus jucundus (Mocsáry, 1883) - Sbt, Tsz

Leptochilus regulus (Saussure, 1856) - Sbt

Microdynerus nugdunensis (Saussure, 1856) - KGe,

Mbt, Sbt, Tbt, TD

Microdynerus timidus (Saussure, 1856) - SD

Odynerus melanocephalus (Gmelin, 1790) - TD

Odynerus poecilus Saussure, 1856 - Mbt, SD

Odynerus spinipes (Linnaeus, 1758) - Sbt, SD

Parodontodynerus ephippium (Klug, 1817) - Sbt

Pseudomicrodynerus parvulus (Herrich-Schaeffer, 1838) - KGe, TD

Stenodynerus bluethgeni v. d. Vecht, 1971 - TD

Stenodynerus chevrieranus (Saussure, 1856) - Sbt,

SD, Tsz

Stenodynerus xanthomelas (Herrich-Schaeffer, 1839)

$-\mathrm{SD}, \mathrm{TD}$

Symmorphus bifasciatus (Linnaeus, 1761) - Ksz, SD, TD

Symmorphus debilitatus (Saussure, 1856) - KGe

Symmorphus gracilis (Brullé, 1832) - Ksz, Sbt, SD, Tbt, TD, Ts,

Symmorphus murarius (Linnaeus, 1758) - Sbt

\section{APOIDEA: SPHECIFORMES}

SPHECIDAE

Ammophila campestris Latreille, 1809 - Sbt

Ammophila sabulosa (Linnaeus, 1758) - KGe, Ksz,

Mbt, Sbt, TD

Chalybion femotarum (Fabricius, 1781) - Sbt, Tsz

Isodontia mexicana (Saussure, 1867) - Mbt, Sbt

Podalonia affinis (Kirby, 1798) - Sbt, Tsz

Podalonia hirsuta (Scopoli, 1763) - Sbt

Sceliphron curvatum (Smith, 1870) - Mbt, Sbt

Sceliphron destillatorium (Illiger, 1807) - Sbt, Tbt, TD

CRABRONIDAE: ASTATINAE

Astata boops (Schrank, 1781) - Sbt, TD

Astata kashmirensis Nurse, 1909 - Sbt

Astata minor Kohl, 1895 - Sbt

Dinetus pictus (Fabricius, 1793) - Sbt

CRABRONIDAE: BEMBICINAE

Alysson spinosus (Panzer, 1801) - Sbt, Tbt, TD

Alysson tricolor Lepeletier \& Serville, 1825 - Sbt

Argogorytes fargeii (Shuckard, 1837) - TD

Argogorytes mystaceus (Linnaeus, 1761) - SD, TD

Didineis lunicornis (Fabricius, 1798) - Sbt

Gorytes fallax Handlirsch, 1888 - Mbt, Sbt, SD

Gorytes laticinctus (Lepeletier, 1832) - Mbt, Sbt, SD

Gorytes procrustes Handlirsch, $1888-\mathrm{Mbt}$

Gorytes quadrifasciatus (Fabricius, 1804) - SD

Gorytes quinquecinctus (Fabricius, 1793) - Ksz, Sbt,

$\mathrm{SD}, \mathrm{TD}, \mathrm{Ts}$

Harpactus affinis (Spinola, 1808) - TD

Harpactus elegans (Lepeletier, 1832) - Sbt

Harpactus laevis (Latreille, 1792) - Sbt, SD

Nysson dimidiatus Jurine, 1807 - Sbt

Nysson interrutus (Fabricius, 1798) - TD 
Nysson spinosus (Forster, 1771) - KGe Nysson trimaculatus (Rossi, 1790) - Sbt

\section{CRABRONIDAE: CRABRONINAE}

Crabro cribrarius (Linnaeus, 1758) - TD

Crossocerus acanthophorus (Kohl, 1892) - Sbt

Crossocerus annulipes (Lepeletier \& Brullé, 1835) Sbt, Tbt, TD

Crossocerus assimilis (Smith, 1856) - Mbt

Crossocerus cetratus (Shuckard, 1837) - TD

Crossocerus distinguendus (Morawitz, 1866) - Tbt, TD

Crossocerus elongatulus (Vander Linden, 1829) - Sbt, Tbt, TD

Crossocerus exiguus (Vander Linden, 1829) - Sbt, Tbt, TD

Crossocerus nigritus (Lepeletier \& Brullé, 1835) Sbt,

Crossocerus ovalis Lepeletier \& Brullé, 1834 - KGe, $\mathrm{Sbt}$

Crossocerus podagricus (Vander Linden, 1829) Mbt, Sbt, SD, Tbt, TD

Crossocerus pusillus Lepeletier \& Brullé, 1834 - SD

Crossocerus quadrimaculatus (Fabricius, 1793) - Sbt,

$\mathrm{Tbt}$

Crossocerus tarsatus (Shuckard, 1837) - Tbt

Ectemnius cephalotes (Olivier, 1792) - Sbt, Tbt

Ectemnius confinis (Walker, 1871) - Ksz, Sbt, TD

Ectemnius continuus (Fabricius, 1804) - Mbt, Sbt, SD, TD

Ectemnius dives (Lepeletier \& Brullé, 1835) - Ksz,

Sbt, Tbt, TD

Ectemnius fossorius (Linnaeus, 1758) - KGe

Ectemnius lapidarius (Panzer, 1804) - Ksz, Mbt, Sbt,

$\mathrm{SD}$, Ts

Ectemnius lituratus (Panzer, 1804) - KGe, Sbt, SD,

TD

Ectemnius meridionalis (Costa, 1871) - Sbt

Ectemnius rubicola (Dufour \& Perris, 1840) - KGe, Mbt, Sbt, SD, TD

Ectemnius rugifer (Dahlbom, 1845) - Sbt, SD, TD

Entomognathus brevis (Vander Linden, 1829) - KGe,

Mbt, Sbt, TD

Entomognathus dentifer (Noskiewicz, 1929)

Lestica alata (Panzer, 1797) - Sbt

Lestica clypeata (Schreber, 1759) - Mbt, Sbt, SD, TD

Lindenius albilabris (Fabricius, 1793) - Mbt, Ksz,

Sbt, SD, TD

Lindenius laevis Costa, 1871 - TD

Lindenius panzeri (Vander Linden, 1829) - TD

Lindenius parkanensis Zavadil, 1948 - TD

Lindenius pygmaeus armatus (Vander Linden, 1829)

- Mbt, Sbt, Tbt

Miscophus ater Lepeletier, 1845 - Sbt

Miscophus bicolor Jurine, 1807 - Sbt

Miscophus niger Dahlbom, 1844 - Sbt

Nitela fallax Kohl, 1884 - Tbt - SD

Nitela spinolae Latreille, 1809 - Sbt

Oxybelus bipunctatus Olivier, 1811 - Mbt, Sbt, TD

Oxybelus mucronatus (Fabricius, 1793) - Ksz, Sbt,

SD, TD

Oxybelus quatordecimnotatus Jurine, 1807 - Mbt,

Sbt, TD

Oxybelus trispinosus (Fabricius, 1787) - SD, Tsz

Oxybelus uniglumis (Linnaeus, 1758) - Mbt

Oxybelus variegatus Wesmael, 1852 - Ksz, Sbt, TD

Oxybelus victor Lepeletier, 1845 - Sbt, Tsz

Palarus variegatus (Fabricius, 1781) - TD
Pison atrum (Spinola, 1808) - Sbt

Rhopalum coarctatum (Scopoli, 1763) - Tbt

Rhopalum gracile Wesmael, 1852 - SD, TD

Solierella compedita (Piccioli, 1869) - Sbt

Tachysphex pompiliformis (Spinola, 1805) - Sbt

Tachysphex psammobius (Kohl, 1880) - Sbt

Tachysphex tarsinus (Lepeletier, 1845) - Sbt

Trypoxylon attenuatum Smith, 1851 - Sbt, SD, TD

Trypoxylon clavicerum Lepeletier \& Serville, 1828 Sbt, Tbt

Trypoxylon figulus (Linnaeus, 1758) - Mbt, Sbt, SD

Trypoxylon medium Beaumont, 1945 - TD

Trypoxylon scutatum Chevrier, 1867 - Sbt

CRABRONIDAE: MELLINAE

Mellinus arvensis (Linnaeus, 1758) - Sbt

\section{CRABRONIDAE: PEMPHREDONINAE}

Ammoplanus hofferi Snoflak, 1943 - Sbt

Diodontus brevilabris Beaumont, 1967 - Ksz, Mbt,

Sbt, Tbt

Diodontus luperus Shuckard, 1837 - Sbt

Diodontus minutus (Fabricius, 1793) - Sbt, TD

Diodontus tristis (Vander Linden, 1829) - Sbt, Tbt

Mimesa equestris (Fabricius, 1804) - Ksz

Mimumesa dahlbomi (Wesmael, 1852) - SD, TD

Mimumesa unicolor (Vander Linden, 1829) - Sbt, TD

Passaloecus clypealis Faester, 1847 - SD

Passaloecus corniger Shuckard, 1837 - Sbt

Passaloecus gracilis (Curtis, 1834) - Sbt, SD, TD

Passaloecus insignis (Vander Linden, 1829) - Tbt

Passaloecus pictus Ribaut, 1952 - Sbt

Passaloecus singularis Dahlbom, 1844 - KGe, Sbt Pemphredon inornata Say, 1824 - Mbt, Sbt, SD, Tbt, TD

Pemphredon lethifera (Shuckard, 1837) - Sbt, SD,

Tbt, TD

Pemphredon lugubris (Panzer, 1793) - Sbt

Pemphredon morio Vander Linden, 1829 - Sbt

Pemphredon rugifera (Dahlbom, 1844) - Sbt

Psen ater (Olivier, 1792) - Ksz

Psenulus chevrieri (Tournier, 1889) - Sbt, SD

Psenulus fuscipennis (Dahlbom, 1849) - Sbt, SD

Psenulus laevigatus (Schenck, 1857) - Sbt

Psenulus pallipes (Panzer, 1798) - Fsz, Sbt, TD

Psenulus schencki (Tournier, 1889) - Sbt, SD

Spilomena beata Blüthgen, 1953 - Sbt

Spilomena mocsaryi Kohl, 1888 - Sbt

Spilomena troglodytes (Vander Linden, 1829) - Sbt, Tbt

Stigmus pendulus Panzer, 1804 - Sbt, Tbt

Stigmus solskyi Morawitz, 1864 - Sbt, SD, Tbt, TD

\section{CRABRONIDAE: PHILANTHINAE}

Cerceris albofasciata (Rossi, 1790) - Mbt, Sbt

Cerceris arenaria (Linnaeus, 1758) - Sbt, Tbt, TD

Cerceris flavilabris (Fabricius, 1793) - Sbt

Cerceris hortivaga Kohl, 1880 - Mbt, Ksz, Sbt, SD, TD

Cerceris interrupta (Panzer, 1799) - Mbt, Sbt

Cerceris quadricincta (Panzer, 1799) - Sbt, SD, TD, Ts

Cerceris quinquefasciata (Rossi, 1792) - Sbt, SD, TD, $\mathrm{Tbt}$

Cerceris rubida (Jurine, 1807) - Sbt, TD

Cerceris rybyensis (Linnaeus, 1771) - TD, Ts

Cerceris ruficornis (Fabricius, 1793) - Ksz, Mbt, Sbt

Cerceris sabulosa (Panzer, 1799) - Mbt, Sbt, SD, Tbt, TD 
Philanthus triangulum (Fabricius, 1775) - Ksz, Sbt, TD

\section{APOIDEA: ANTHOPHILA \\ ANDRENIDAE}

Andrena aeneiventris Morawitz, 1872 - Mbt, Sbt, $\mathrm{SD}$

Andrena alfkenella Perkins, 1914 - Ksz, SD

Andrena barbilabris (Kirby, 1802) - SD

Andrena bicolor Fabricius, 1775 - Mda, SD

Andrena bimaculata (Kirby, 1802) - Sbt, SD, TD

Andrena bisulcata Morawitz, 1877 - Sbt

Andrena bucephala Stephens, 1846 - Sbt, SD, TD

Andrena chysopyga Schenck, 1853 - Sbt, SD

Andrena chrysosceles (Kirby, 1802) - SD

Andrena cineraria (Linnaeus, 1758) - Sbt, SD, Ts

Andrena curvana Warncke, 1965 - KGe, Sbt, SD

Andrena denticulata (Kirby, 1802) - Ksz, Sbt, SD

Andrena dorsalis Brullé, 1832 - MDa, SD, TD

Andrena dorsata (Kirby, 1802) - Mbt, Sbt, SD, TD

Andrena enslinella Stöckhert, 1924 - SD

Andrena falsifica Perkins. 1915 - KGe, SD

Andrena flavipes Panzer, 1799 - Ksz, Mbt, Sbt, SD, TD

Andrena floricola Eversmann, 1852 - Sbt, SD

Andrena fulva (Müller, 1766) - SD

Andrena fulvata Stöckhert, 1930 - Sbt, SD

Andrena fulvicornis Schenck, 1853 - KGe, Mbt, SD

Andrena gravida Imhoff, 1832 - KGe, Mbt, Sbt, SD, TD, Tsz

Andrena haemorrhoa (Fabricius, 1781) - KGe, Mbt,

Sbt, SD, TD

Andrena hattorfiana (Fabricius, 1775) - Mbt, Sbt, SD,

Tsz

Andrena hedikae Jaeger, 1934 - Mbt

Andrena helvola (Linnaeus, 1758) - KGe, Mbt, SD

Andrena humilis Imhoff, 1832 - Ksz,

Andrena impunctata Pérez, 1895 - Mbt, Sbt

Andrena jacobi Perkins, 1921 - Ksz, MDa

Andrena labialis (Kirby, 1802) - Mbt, SD, TD

Andrena labiata Fabricius, 1781 - Sbt

Andrena lagopus Latreille, 1809 - Mbt, MDa, SD, TD

Andrena limata Smith, 1853 - KGe, SD, Tsz

Andrena marginata Fabricius, 1776 - Sbt, Tsz

Andrena minutula (Kirby, 1802) - Ksz, Mbt, Sbt, SD,

TD

Andrena minutuloides Perkins, 1914 - Ksz, Mbt, Sbt,

$\mathrm{SD}$, Ts

Andrena mitis Schmiedeknecht, 1883 - Sbt, SD

Andrena nana (Kirby, 1802) - Sbt

Andrena nasuta Giraud, 1863 - Mbt

Andrena nigroaenea (Kirby, 1802) - Mbt, MDa, SD

Andrena nitida (Müller, 1776) - Mbt, MDa, Sbt, SD,

TD

Andrena nitidiuscula Schenck, 1853 - Mbt, Sbt, TD

Andrena nychtemera Imhoff, 1868 - Sbt, SD

Andrena ovatula (Kirby, 1802) - Mbt, Sbt, SD, TD

Andrena pilipes Fabricius, 1781 - SD

Andrena praecox (Scopoli, 1763) - KGe, Sbt, SD, Mbt,

Andrena propinqua Schenck, 1853 - Sbt, SD, TD

Andrena proxima (Kirby, 1802) - Mbt, SD, TD

Andrena rosae Panzer, 1801 - Ksz, Sbt, SD

Andrena rufula Schmiedeknecht, 1883 - SD, Ts

Andrena saxonica Stöckhert, 1935 - SD

Andrena schencki Morawitz, 1866 - SD

Andrena schlettereri Friese, 1896 - Sbt, Tsz

Andrena seminuda Friese, 1896 - MDa, SD
Andrena sericata Imhoff, 1868 - Mbt, MDa, Sbt, SD Andrena simontornyella Noskiewicz, 1939 - Ksz, $\mathrm{MDa}, \mathrm{Sbt}, \mathrm{SD}, \mathrm{TD}$

Andrena strohmella Stöckhert, 1928 - SD

Andrena subopaca Nylander, 1848 - Mbt, SD, Tsz

Andrena susterai Alfken, 1914 - KGe, Mbt, Sbt, SD,

TD, Ts

Andrena symphyti Schmiedeknecht, 1883 - Sbt, SD, TD

Andrena taraxaci Giraud, 1861 - Sbt, SD, MDa

Andrena tibialis (Kirby, 1802) - Mbt, Sbt, SD, TD

Andrena tscheki Morawitz, 1872 - SD

Andrena vaga Fabricius, 1799 - Sbt, SD, TD

Andrena varians (Kirby, 1802) - Sbt, Tsz

Andrena ventralis Imoff, 1832 - Sbt, SB

Andrena viridescens Viereck, 1916 - KGe, Ksz

Melitturga clavicornis (Latreille, 1806) - Sbt, SD

Panurgus calcaratus (Scopoli, 1763) - Sbt, SD, TD

APIDAE: APINAE

Amegilla salviae (Morawitz, 1856) - Sbt

Anthophora crinipes Smith, 1854 - Mbt, Sbt

Anthophora furcata (Panzer, 1798) - Mbt, Sbt, Tsz

Anthophora plumipes (Pallas, 1772) - Sbt, SD

Anthophora pubescens (Fabricius, 1781) - KGe, Sbt,

Bombus haematurus Kriechbaumer, 1870 - MDa, SD

Bombus hortorum (Linnaeus, 1761) - Mbt, Sbt, SD,

TD

Bombus hypnorum (Linnaeus, 1758) - SD

Bombus lapidarius (Linnaeus, 1758) - Sbt

Bombus lucorum (Linnaeus, 1761) - MGe

Bombus muscorum (Linnaeus, 1758) - Sbt

Bombus pascuorum ((Scopoli, 1763) - MDa, Sbt, TD

Bombus paradoxus Dalla-Torre, 1882 - Sbt

Bombus pratorum (Linnaeus, 1761) - SD

Bombus ruderarius (Müller, 1776) - Sbt, Tsz

Bombus sylvarum (Linnaeus, 1761) - Sbt, SD, Tsz

Bombus terrestris (Linnaeus, 1758) - Sbt, SD

Psithyrus barbutellus (Kirby, 1802) - KGe

Eucera clypeata Erichson, 1835 - Sbt

Eucera interrupta Baer, 1850 - Sbt, Tsz

Eucera longicornis (Linnaeus, 1758) - KGe, Sbt, TD

Eucera nigrescens Pérez, 1879 - Mbt, Sbt, SD, TD

Eucera nitidiventris Mocsáry, 1879 - Sbt

Eucera pollinosa Smith, 1854 - Sbt

Melecta albifrons (Forster, 1771) - Tsz

Tetralonia malvae (Rossi, 1790) - Tsz

Tetraloniella alticincta (Lepeletier, 1841) - KGe, TD

Tetraloniella nana (Morawitz, 1874) - Sbt, TD

Tetraloniella salicariae (Lepeletier, 1841) - TD

Thyreus orbatus (Lepeletier, 1841) - Tsz

Thyreus ramosus (Lepeletier, 1841) - Mbt, Sbt, Tsz

APIDAE: NOMADINAE

Biastes brevicornis (Panzer,1798) - Sbt

Nomada alboguttata Herrich-Schaeffer, 1839 - MDa, Sbt, TD

Nomada argentata Herrich-Schaeffer, 1839 - Sbt, TD

Nomada armata Herrich-Schaeffer, 1839 - Mbt, SD,

Tsz

Nomada atroscutellaris Strand, 1921-KGa, SD, Ksz

Nomada bifasciata Olivier, 1811 - KGe, Mbt, Sbt, SD, TD, Ts

Nomada bluethgeni Stöckhert, 1943 - Sbt, Tsz

Nomada braunsiana Schmiedeknecht, 1882 - KGe,

$\mathrm{SD}$, Ts

Nomada castellana Dusmet, 1913 - TD

Nomada conjungens Herrich-Schaeffer, 1839 - KGe,

Sbt, SD, TD 
Nomada distinguenda Morawitz, 1874 - Sbt, SD, Tsz

Nomada emarginata Morawitz, 1877 - Sbt

Nomada fabriciana (Linnaeus, 1767) - KGe, SD, TD,

Ts

Nomada ferruginata (Linnaeus, 1767) - MDa, Sbt, $\mathrm{SD}, \mathrm{TD}$, Ts

Nomada flava Panzer, 1798 - SD, TD, Ts

Nomada flavoguttata (Kirby, 1802) - KGe, Sbt, SD, Mbt, TD

Nomada flavopicta (Kirby, 1802) - Sbt, SD, Tsz

Nomada fucata Panzer, 1798 - Mbt, Sbt, SD, Tsz

Nomada fulvicornis Fabricius, 1793 - MDa, Sbt, SD,

TD

Nomada furva Panzer, 1798 - Sbt, SD

Nomada fuscicornis Nylander, 1848 - SD, TD

Nomada goodeniana (Kirby, 1802) - MDa, Sbt, SD,

TD, Ts

Nomada hirtipes Pérez, 1884 - SD

Nomada incisa Schmiedeknecht, 1882 - KGe

Nomada lathburiana (Kirby, 1802) - TD, Ts

Nomada panzeri Lepeletier, 1841 - KGe, SD, TD, Ts,

Nomada panzeri hybrida Schmiedeknecht, 1882 -

TD, Ts

Nomada platythorax Schwarz, 1981 - Sbt

Nomada pleurosticta Herrich-Schaeffer, 1839 - Ksz, TD

Nomada posthuma Blüthgen, 1989 - SD

Nomada ruficornis (Linnaeus, 1758) - KGe, MDa, SD, TD

Nomada rufipes Fabricius, 1793 - SD, TD

Nomada sexfasciata Panzer, 1799 - KGe, Mbt, SD, TD, Tsz

Nomada sheppardana (Kirby, 1802) - KGe, SD

Nomada stigma Fabricius, 1804 - Tsz

Nomada succincta Panzer, 1798 - Mbt, MDa, Sbt, SD

Nomada symphyti Stöckhert, 1930 - KGe, Mbt, SD

Nomada trispinosa Schmiedeknecht, 1882 - Mbt, TD

Nomada villosa Thomson, 1870 - KGe

Nomada zonata Panzer, 1798 - KGe, SD, Ts

Pasites maculatus Jurine, 1807 - Mbt

Triepeolus tristis (Smith, 1854) - Sbt, Tsz

\section{APIDAE: XYLOCOPINAE}

Ceratina chalybea Chevrier, $1872-\mathrm{KGe}$, Sbt, SD, Tsz

Ceratina cucurbitina (Rossi, 1792) - Sbt

Ceratina cyanea (Kirby, 1802) - Sbt, SD, TD

\section{COLLETIDAE}

Colletes cunicularius (Linnaeus, 1761) - KGe, Mbt, MDa, Sbt, SD, TD

Colletes daviesanus Smith, 1846 - Mbt, Sbt, Tsz Colletes inexpectatus Noskiewicz, 1936 - Sbt

Colletes mlokossewiczi Radoszkowski, 1891 - Sbt

Colletes similis Schenck, 1859 - Sbt, TD

Hylaeus angustatus (Schenck, 1859) - KGe, TD

Hylaeus annularis (Kirby, 1802) - Ksz, Sbt, TD

Hylaeus brevicornis Nylander, 1852 - Mbt, Sbt, SD, TD

Hylaeus cardioscapus Cockerell, 1924 - Mbt

Hylaeus communis Nylander, 1852 - KGe, Ksz, Sbt, SD, TD

Hylaeus confusus Nylander, 1852 - MGe, SD, TD

Hylaeus cornutus Curtis, 1831 - Mbt, Ksz, Sbt, SD, TD
Hylaeus difformis (Eversmann, 1852) - Sbt, SD Hylaeus duckei (Alfken, 1904) - KGe, Sbt, Mbt Hylaeus gibbus Saunders, 1850 - Ksz, KGe, Mbt, SD

Hylaeus gredleri Förster, 1871 - TD

Hylaeus hyalinatus Smith, 1842 - Mbt, Sbt, TD

Hylaeus leptocephalus (Morawitz, 1870) - Sbt, SD, Tsz

Hylaeus nigritus (Fabricius, 1798) - Ksz, Mbt, Sbt

Hylaeus punctatus (Brullé, 1832) - Mbt, Sbt, TD

Hylaeus punctulatissimus Smith, 1842 - Tsz

Hylaeus signatus (Panzer, 1798) - Mbt

Hylaeus sinuatus (Schenck, 1853) - Mbt, Sbt, SD

Hylaeus styriacus Förster, 1871 - Mbt, Sbt, SD, TD

Hylaeus variegatus (Fabricius, 1798) - Ksz, Sbt, SD, TD

\section{HALICTIDAE}

Halictus asperulus Pérez, 1895 - Sbt

Halictus eurygnathus Blüthgen, 1931 - Mbt, Ksz, Sbtt, SD, TD

Halictus kessleri Bramson, 1879 - Mbt, Sbt, TD

Halictus langobardicus Blüthgen, 1944 - KGe, Ksz, Sbt, SD, TD

Halictus leucaheneus Ebmer, 1972 - Sbt

Halictus maculatus Smith 1848 - Mbt, Sbt, SD, TD

Halictus pollinosus Sichel, 1860 - Mbt

Halictus quadricinctus (Fabricius, 1776) - Sbt

Halictus rubicundus (Christ, 1791) - SD, TD

Halictus scabiosae (Rossi, 1790) - Tsz

Halictus seladonius (Fabricius, 1794) - Sbt

Halictus sexcinctus (Fabricius, 1775) - Sbt, TD

Halictus simplex Blüthgen, 1923 - Sbt, TD

Halictus subauratus (Rossi, 1792) - KGe, Mbt, Sbt, SD, Tsz

Halictus tumulorum (Linnaeus, 1758) - SD, TD

Lasioglossum albipes (Fabricius, 1781) - Sbt

Lasioglossum angusticeps (Perkins, 1895) - SD

Lasioglossum bluethgeni Ebmer, 1971 - KGe

Lasioglossum brevicorne (Schenck, 1869) - SD

Lasioglossum buccale (Pérez, 1903) - Sbt

Lasioglossum calceatum (Scopoli, 1763) - Sbt, SD, TD

Lasioglossum costulatum (Kriechbaumer, 1873) $\mathrm{SD}$

Lasioglossum discum (Smith, 1853) - Sbt

Lasioglossum glabriusculum (Morawitz, 1872) - Sbt, $\mathrm{SD}, \mathrm{TD}$

Lasioglossum interruptum (Panzer, 1798) - Sbt, TD, Tsz

Lasioglossum laeve (Kirby, 1802) - Sbt

Lasioglossum laevigatum (Kirby, 1802) - MDa, Sbt Lasioglossum laterale (Brullé, 1832) - KGe, Mbt, $\mathrm{SD}$

Lasioglossum laticeps (Schenck, 1869) - Mbt, Sbt, $\mathrm{SD}, \mathrm{TD}$

Lasioglossum lativentre (Schenck, 1853) - Sbt, SD

Lasioglossum leucozonium (Schrank, 1781) - Sbt, TD

Lasioglossum lineare (Schenck, 1869) - SD

Lasioglossum lucidulum (Schenck, 1861) - Mbt, Sbt

Lasioglossum majus (Nylander, 1852) - Sbt, TD

Lasioglossum malachurum (Kirby, 1802) - KGe, Sbt, $\mathrm{SD}, \mathrm{TD}$

Lasioglossum marginatum (Brullé, 1832) - MDa, Sbt, $\mathrm{SD}, \mathrm{TD}$

Lasioglossum minutissimum (Kirby, 1802) - SD, TD

Lasioglossum morio (Fabricius, 1793) - Mbt, Sbt, SD, TD 
Lasioglossum nigripes (Lepeletier, 1841) - Sbt, SD, TD

Lasioglossum nitidiusculum (Kirby, 1802) - Mbt, Sbt, TD

Lasioglossum nitidulum (Fabricius, 1804) - Mbt, Tbt Lasioglossum pallens (Bullé, 1832) - Sbt, SD, TD

Lasioglossum parvulum (Schenck, 1853) - SD, TD Lasioglossum pauxillum (Schenck, 1853) - KGe, Mbt, Ksz, Sbt, SD, TD

Lasioglossum politum (Schenck, 1853) - KGe, Mbt, Sbt, SD, TD

Lasioglossum punctatissimum (Schenck, 1853) - SD, TD

Lasioglossum puncticolle (Morawitz, 1872) - KGe

Lasioglossum pygmaeum (Schenck, 1853) - Sbt

Lasioglossum quadrinotatulum (Schenck, 1853) Sbt, TD

Lasioglossum semilucens (Alfken, 1914) - Sbt, SD, TD

Lasioglossum sexnotatum (Kirby, 1802) - Sbt, SD

Lasioglossum sexstrigatum (Schenck, 1869) - Ksz, Sbt

Lasioglossum trichopygum (Blüthgen, 1923) - Mbt, Sbt

Lasioglossum xanthopus (Kirby, 1802) - Sbt

Lasioglossum zonulum (Smith, 1848) - Sbt, SD, TD

Nomiapis bispinosa (Brullé, 1832) - Sbt

Nomiapis diversipes (Latreille, 1806) - Mbt, Sbt

Rophites hartmanni Friese, 1902 - Sbt

Rophites quinquespinosus Spinola, 1808 - SD

Rophitoides canus (Eversmann, 1852) - Sbt, TD

Sphecodes albilabris (Fabricius, 1793) - Mbt, MDa,

SD, TD, Tsz

Specodes crassus Hagens, 1882 - Sbt

Sphecodes ephippius (Linnaeus, 1767) - KGe, Sbt, $\mathrm{SD}, \mathrm{TD}$

Sphecodes ferruginatus Hagens, 1882 - KGe, Mbt Sphecodes gibbus (Linnaeus, 1758) - KGe, Mbt, Sbt, SD, TD, Tsz

Sphecodes longulus Hagens, 1882 - Sbt, SD, TD Sphecodes majalis Pérez, 1903 - KGe, MDa, SD, TD, Ts

Sphecodes miniatus Hagens, 1882 - Mbt, Sbt Sphecodes monilicornis (Kirby, 1802) - KGe, Sbt, SD, TD

Sphecodes niger Hagens, 1874 - Sbt, SD, TD

Sphecodes pellucidus Smith, 1845 - Sbt, TD

Sphecodes puncticeps Thomson, 1870 - KGe, Sbt

Sphecodes rubicundus Hagens, 1875 - SD

Sphecodes rufiventris (Panzer, 1789) - Sbt, Tsz

Sphecodes scabricollis Wesmael, 1865 - SD

Systropha curvicornis ((Scopoli, 1770) - Sbt

Systropha planidens Giraud, 1861 - TD

\section{MEGACHILIDAE}

Anthidium florentinum (Fabricius, 1775) - Sbt

Anthidium manicatum (Linnaeus, 1758) - Mbt, Sbt,

Tsz

Anthidium nanum Mocsáry, 1881 - TD

Anthidium oblongatum (Illiger, 1806) - Mbt, Sbt, TD

Anthidium strigatum (Panzer, 1805) - Sbt, SD

Chelostoma campanularum (Kirby, 1802) - Mbt, Sbt, SD, TD

Chelostoma distinctum (Stöckhert, 1929) - KGe, Ksz, Sbt, TD
Chelostoma emarginatum (Nylander, 1856) - Ksz, SD

Chelostoma florisomne (Linnaeus, 1758) - Sbt, SD

Chelostoma rapunculi (Lepeletier, 1841) - Mbt, TD

Chelostoma styriacum Schwarz \& Gusenleitner, 1999

- SD

Chelostoma ventrale Schletterer, 1889 - Ksz, Sbt

Coelioxys afra Lepeletier, 1841 - Tsz

Coelioxys aurolimbata Förster, 1853 - Sbt, Tsz

Coelioxys echinata Förster, 1853 - TD

Coelioxys elongata Lepeletier, 1841 - SD

Coelioxys inermis (Kirby, 1802) - Mbt, SD

Coelioxys mandibularis Nylander, 1843 - Sbt

Coelioxys obtusa Pérez, 1884 - Sbt

Coelioxys quadridentata (Linnaeus, 1761) - Sbt

Coelioxys rufescens Lepeletier \& Serville, 1825 $\mathrm{Mbt}, \mathrm{Sbt}$

Heriades crenulatus Nylander, 1856 - SD, TD

Heriades truncorum (Linnaeus, 1758) - Mbt, Sbt, SD

Hoplosmia bidentata (Morawitz, 1876) - Sbt

Hoplosmia spinulosa (Kirby, 1802) - Sbt, SD

Hoplitis claviventris (Thomson, 1872) - KGe, Mbt, TD

Hoplitis leucomelana (Kirby, 1802) - KGe, Mbt, Sbt, SD, TD

Hoplitis manicata (Morice, 1901) - Sbt

Hoplitis papaveris (Latreille, 1799) - Sbt

Lithurgus chrysurus Fonscolombe, 1834 - TD

Lithurgus cornutus (Fabricius, 1787) - Sbt

Megachile apicalis Spinola, 1808 - Sbt, Tsz

Megachile centuncularis (Linnaeus, 1758) - Mbt, Sbt, SD, TD

Megachile ericetorum Lepeletier, 1841 - Mbt, Sbt, TD

Megachile genalis Morawitz, 1880 - Tsz

Megachile leachella Curtis, 1828 - Mbt

Megachile maritima (Kirby, 1802) - TD

Megachile pilicrus Morawitz, 1877 - Sbt, Tsz

Megachile pilidens Alfken, 1924 - Mbt, Sbt

Megachile rotundata (Fabricius, 1787) - Sbt, TD

Megachile versicolor Smith, 1844 - Tsz

Megachile willughbiella (Kirby, 1802) - Sbt, TD

Osmia aurulenta (Panzer, 1799) - Mbt, SD, TD

Osmia bicolor (Schrank, 1781) - MDa, SD

Osmia caerulescens (Linnaeus, 1758) - Mbt, Sbt, SD, TD

Osmia cornuta (Latreille, 1805) - Sbt, SD, TD

Osmia leaiana (Kirby, 1802) - KGe, Sbt, SD

Osmia melanogaster Spinola, 1808 - Mbt, Sbt

Osmia niveata (Fabricius, 1804) - KGe

Osmia pilicornis Smith, 1846 - SD

Osmia rufa (Linnaeus, 1758) - KGe, MDa, Sbt, SD, Ts

Osmia rufohirta Latreille, 1811 - Sbt, Tsz

Stelis breviuscula (Nylander, 1848) - SD

Stelis iugae Noskiewicz, 1862 - Sbt

Stelis punctulatissima (Kirby, 1802) - Tsz

\section{MELITTIDAE}

Dasypoda hirtipes (Fabricius, 1793) - Sbt. TD

Macropis fulvipes (Fabricius, 1804) - KGe

Macropis europaea Warncke, 1973 - SD

Melitta leporina (Panzer, 1799) - Sbt

Melitta nigricans Alfken, 1905 - Ksz, Sbt, SD 


\section{Irodalom}

JózAn Zs. 1990: A Zselic méhszerü (Hymenoptera), Apoidea faunájának alapvetése. - A Janus Pannonius Múzeum Évkönyve 34 (1989): 81-92.

JózAn Zs. 1992a: A Béda-Karapancsa Tájvédelmi Körzet fullánkos hártyásszárnyú (Hymenoptera, Aculeata) faunájának alapvetése. - Dunántúli Dolgozatok Természettudományi Sorozat 6: 219-246.

JózAN Zs. 1992b: A Boronka-melléki Tájvédelmi Körzet fullánkos hártyásszárnyú (Hymenoptera, Aculeata) faunájának alapvetése. - Dunántúli Dolgozatok Természettudományi Sorozat 7: 163-210.

JózAN Zs. 1992c: A Zselic darázsfaunájának (Hymenoptera, Aculeata) állatföldrajzi és ökofaunisztikai vizsgálata. - Somogyi Múzeumok Közleményei 9: 279-292.

JózAN Zs. 1996: A Baláta környék fullánkos hártyásszárnyú faunájának (Hym., Aculeata) alapvetése. Somogyi Múzeumok Közleményei 12: 271-297.

JózAn Zs. 1998: A Duna-Dráva Nemzeti Park fullánkos hártyásszárnyú (Hymenoptera, Aculeata) faunája. Dunántúli Dolgozatok Természettudományi Sorozat 9: 291-327.

JózAN Zs. 2000a: A Villányi-hegység fullánkos hártyásszárnyú (Hymenoptera, Aculeata) faunája. - Dunántúli Dolgozatok Természettudományi Sorozat 10: 267-283.

JózAN Zs. 2000b: Külső-Somogy méhszerü (Hymenoptera, Apoidea) faunája. - Somogyi Múzeumok Közleményei 14: 307-330.

JózAN Zs. 2003: A Látrányi Puszta Természetvédelmi Terület fullánkos hártyásszárnyú (Hymenoptera, Aculeata) faunája. - Natura Somogyiensis 5: 209-233.

JózAN Zs. 2006: A Mecsek fullánkos hártyásszárnyú faunája (Hymenoptera, Aculeata). - Folia Comloensis 15: 219-238.

JóZAN Zs. 2008: Új kaparódarázs fajok (Hymenoptera, Sphecidae) Magyarország faunájában. - Somogyi Múzeumok Közleményei 18: 81-83.

JózAN Zs. 2015: A Barcsi borókás fullánkos faunája, III. (Hymenoptera: Aculeata). - Natura Somogyiensis 26: 95-108.

JózAN Zs. 2020: Egy zselici löszmélyút fullánkos (Hymenoptera, Aculeata) fajai. - Natura Somogyiensis 35: $119-128$.

MóczÁr L. 1956: Pókölődarázs alkatúak - Pompiloidea. - In: Magyarország Állatvilága (Fauna Hungariae) $\mathrm{XIII} / 5: 1-76$.

MóczÁr L. 1958: A Crabroninae (Fam.: Sphecidae) alcsalád faunakatalógusa (Cat. Hym. XIII.). - Folia entomologica hungarica 11: 189-216.

MóczÁr, L 1986: The survey of the Chrysidoidea, Pompiloidea and Vespoidea fauna of the Kiskunság National Park (Hymenoptera). - In Mahunka, S. (ed.): The Fauna of the Kiskunság National Park, I., Akadémiai Kiadó, Budapest: 383-400.

MóczÁr, L. \& Warncke, K. 1972: Faunenkatalog der Gattung Andrena Fabricius (Cat. Hym. XXVI.). - Acta Biologica Szeged 18 (1-4): 185-221.

MócZÁr M. 1967: Karcsúméhek - Halictidae. - In: Magyarország Állatvilága (Fauna Hungariae) XIII/11: 1-116. 